\title{
Differential Toxicity of Manganese for Virulent and Avirulent Group A Streptococci
}

\author{
By W. FIRSHEIN AND E. M. ZIMMERMAN \\ Department of Biology, Wesleyan University, Middletown, Connecticut, U.S.A.
}

(Received 31 January 1964)

\begin{abstract}
SUMMARY
$\mathrm{Mn}^{2+}$ depressed the rate and extent of multiplication of several virulent strains of group A beta-haemolytic streptococci (Streptococcus pyogenes), and caused a 6-12 hr increase in the lag phases of related avirulent strains. Several other cations did not exert such differential inhibitory effects. $\mathrm{Ca}^{2+}$ overcame the inhibitory effects of $\mathbf{M n}^{2+}$ in both kinds of organism. In suspensions of virulent strains, $\mathbf{M n}^{2+}$ depressed both nucleic acid and protein syntheses below the control values, but only nucleic acid synthesis was depressed in avirulent-organism suspensions; protein synthesis was largely unaffected. The oxidation of glucose was depressed below control values by $\mathrm{Mn}^{2+}$ to a much greater extent in virulent strains than in avirulent strains.
\end{abstract}

\section{INTRODUCTION}

In previous experiments with pneumococci (Streptococcus pneumoniae, Firshein, $1960,1962), \mathrm{Mn}^{2+}$ was shown to stimulate the multiplication of virulent strains and to produce either inhibitory or no effects in the case of avirulent strains. In this respect, $\mathrm{Mn}^{2+}$ acted in a manner similar to that of certain deoxyribonucleic acid (DNA) degradation products, which also enhanced multiplication of virulent strains of pneumococci. However, $\mathrm{Mn}^{2+}$ inhibited the multiplication of several avirulent strains of pneumococci, whereas DNA degradation products did not depress the multiplication of any avirulent strains tested. It was ascertained (Firshein, 1962) that the stimulatory effects of $\mathrm{Mn}^{2+}$ on multiplication of virulent pneumococci were related to an enhancement of respiration, whereas the toxic effects of $\mathbf{M n}^{2+}$ on multiplication of avirulent pneumococci involved, in part, a depressing effect on respiration. Recent results (Firshein \& Zimmerman, 1964) have shown that DNA degradation products also stimulate multiplication of virulent strains of group A streptococci. However, in contrast to pneumococci, these virulent group A streptococci showed a depressed rate and extent of multiplication in the presence of $\mathbf{M n}^{2+}$. The present report is concerned with an analysis of this $\mathrm{Mn}^{2+}$-effect on virulent streptococci as well as with a study of the effects of $\mathrm{Mn}^{2+}$ on multiplication of avirulent streptococci. The effects of $\mathrm{Mn}^{2+}$ on respiration, nucleic acid synthesis, and protein synthesis of both cell types will also be described. In part, the interest of the results with $\mathrm{Mn}^{2+}$ lies in their contrast to the results described in the accompanying paper (Firshein \& Zimmerman, 1964) with DNA degradation products. The results of both papers are discussed together in the next paper (Firshein \& Zimmerman, 1964). 


\section{METHODS}

General. Three pairs of virulent and avirulent strains of group A streptococci were used. They were identical to those used by Firshein \& Zimmerman (1964). Maintenance of these strains, medium, viable counts, techniques of preparing and performing experiments with suspensions of organisms, were as reported by Firshein \& Braun (1960), Firshein (1961) and Firshein \& Zimmerman (1964). $\mathrm{Mn}^{2+}$ (as $\mathrm{MnSO}_{4}$ ) and $\mathrm{Ca}^{2+}\left(\mathrm{as} \mathrm{CaCl}_{2} \cdot 2 \mathrm{H}_{2} \mathrm{O}\right)$ were dissolved in distilled water before use. Other cations
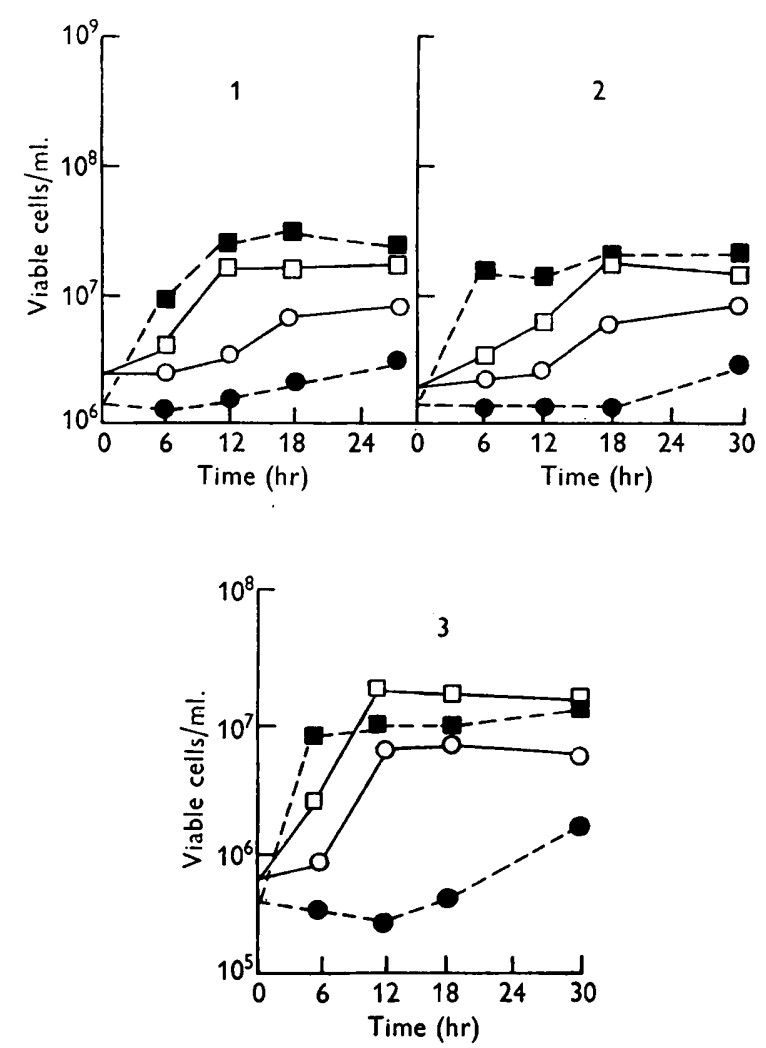

Fig. 1. Viable counts of virulent and avirulent group A streptocosci in the presence and absence of $\mathrm{Mn}^{2+}$. Concentration of $\mathrm{Mn}^{2+}$ was the same for all strains tested $(4 \cdot 0 \mu \mathrm{M})$. Medium was brain heart infusion neopeptone blood broth (Firshein \& Zimmerman, 1964). Virulent, solid lines; avirulent, broken lines. $(O)(\bullet)$, with $\mathrm{Mn}^{2+} ;(\square)(\mathbf{U})$, control. 1 . Strain M-18 (virulent) and $18 \mathrm{AM}^{-}$(avirulent). 2. Strain M-6 (virulent) and $6 \mathrm{AM}^{-}$ (avirulent). 3. Strain Q-43X (virulent) and Q-496 (avirulent).

that were tested included $\mathrm{Mg}^{2+}\left(\right.$ as $\mathrm{MgSO}_{4} \cdot 7 \mathrm{H}_{2} \mathrm{O}$ ), $\mathrm{Zn}^{2+}$ (as $\mathrm{ZnSO}_{4}$ ), and $\mathrm{Fe}^{2+}$ (as $\mathrm{FeSO}_{4}$ ). Manometric experiments were made as described in Firshein \& Zimmerman (1964). As in this latter report, it was necessary to determine the effects of $\mathrm{Mn}^{2+}$ on the length and percentage of chains of cocci in liquid cultures. An effect of $\mathrm{Mn}^{2+}$ on either variable could produce an error in counting the actual number of viable cocci (when this number is determined by plating serial dilutions of the cultures). It was found that $\mathrm{Mn}^{2+}$ had no effects on these variables. 


\section{RESULTS}

\section{Effects of $\mathrm{Mn}^{2+}$ on multiplication}

Figure 1 shows the effects of $\mathrm{Mn}^{2+}$ on the multiplication of virulent and avirulent strains of group A streptococci in broth cultures. In all cases, the same concentration of $\mathrm{Mn}^{2+}(4 \cdot 0 \mu \mathrm{M})$ depressed the rate and extent of multiplication of virulent strains and caused a 6-12 hr increase in the lag phases of avirulent strains. Table 1

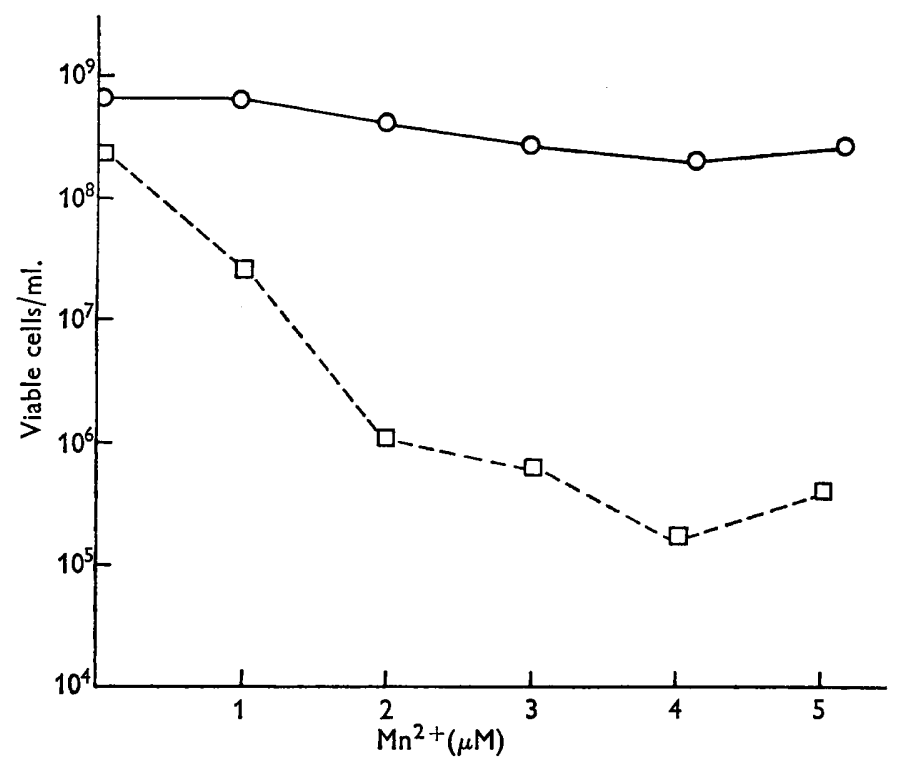

Fig. 2. Effects of concentration of $\mathrm{Mn}^{2+}$ on the number of viable cocci of a virulent and avirulent strain of group A streptococci after incubation for $18 \mathrm{hr}$. Medium was brain heart infusion neopeptone blood broth (Firshein \& Zimmerman, 1964). Inocula $\left(\times 10^{5}\right)$; strain Q-43X (virulent), 50; strain Q-496 (avirulent), 35. Virulent, solid line; avirulent, broken line.

Table 1. Analysis of total yields of organisms and generation times for virulent and avirulent Group A streptococci in the presence and absence of $\mathrm{Mn}^{2+}$

Data are based on results of Fig. 1. Generation times are determined in the log phase of growth, which varied from strain to strain.

\begin{tabular}{|c|c|c|c|c|c|c|}
\hline \multirow[b]{2}{*}{ Organism } & \multicolumn{2}{|c|}{$\begin{array}{c}\text { Yield of cocci } \\
\text { after } 18 \mathrm{hr} \\
\left(\text { Count } \times 10^{5} / \mathrm{ml} .\right)\end{array}$} & \multirow{2}{*}{$\begin{array}{l}\text { Relative } \\
\text { decrease } \\
\text { from } \\
\text { control value* }\end{array}$} & \multicolumn{2}{|c|}{$\begin{array}{l}\text { Generation } \\
\text { time (min.) }\end{array}$} & \multirow{2}{*}{$\begin{array}{c}\text { Relative } \\
\text { increase } \\
\text { from } \\
\text { control value* }\end{array}$} \\
\hline & $\mathrm{Mn}^{2+}$ & Control & & $\mathbf{M n}^{2+}$ & Control & \\
\hline Q-43x (virulent) & 80 & 300 & $\mathbf{3 \cdot 7 5}$ & 52 & 48 & $1 \cdot 1$ \\
\hline Q-496 (avirulent) & 6 & 200 & $\mathbf{3 3} \cdot \mathbf{3}$ & 144 & 23 & $6 \cdot 4$ \\
\hline $\mathrm{M}-18$ (virulent) & 50 & 170 & $3 \cdot 1$ & 190 & 60 & $\mathbf{3} \cdot \mathbf{1}$ \\
\hline $18 \mathrm{AM}^{-}$(avirulent) & 20 & 500 & 25 & 276 & 45 & $6 \cdot 1$ \\
\hline $\mathrm{N}-6$ (virulent) & 65 & 130 & $2 \cdot 0$ & 180 & 70 & $2 \cdot 6$ \\
\hline $6 \mathrm{AM}^{-}$(avirulent) & 15 & 150 & $10 \cdot 3$ & 90 & 18 & $5 \cdot 0$ \\
\hline
\end{tabular}

* These values connote the number of times greater or less, the $\mathrm{Mn}^{2+}$-supplemented values differ from the control values. 
compares the generation times and total yields of avirulent and virulent organisms in the presence and absence of $\mathrm{Mn}^{2+}$. After incubation for $18 \mathrm{hr}$, viable counts in the presence of $\mathrm{Mn}^{2+}$ were much smaller for avirulent cultures than for virulent cultures. Similarly, the rates of multiplication of avirulent strains were lower than those of virulent strains, as evidenced by changes in the generation times. The actual duration of the lag and log phases remained essentially unaltered in $\mathbf{M n}^{\mathbf{2}}$-supplemented and unsupplemented cultures of virulent strains. However, with avirulent strains, the length of these two phases was drastically altered in the presence of $\mathrm{Mn}^{2+}$. Thus, by the time avirulent cocci from unsupplemented cultures had been in the stationary phase for $\mathbf{6 - 1 2} \mathrm{hr}$, avirulent cocci from cultures containing $\mathbf{M n}^{2+}$ were just beginning to enter the log phase.

Table 2. Effects of $\mathrm{Mn}^{2+}$ on multiplication of group A streptococci in different media

Concentration of $\mathrm{Mn}^{2+}$ was $4 \cdot 0 \mu \mathrm{M}$. Inocula $\left(\times 10^{5}\right):$ strain $\mathrm{Q}-43 \mathrm{x}, 10$; strain $\mathrm{Q}-496,14$; strain $\mathrm{M}-18,6.8$; strain $18 \mathrm{AM}^{-}, 12$.

\begin{tabular}{|c|c|c|c|c|}
\hline \multirow[b]{2}{*}{ Medium } & \multirow[b]{2}{*}{ Organism } & \multicolumn{2}{|c|}{ Additions } & \multirow{2}{*}{$\begin{array}{c}\text { Viable cell } \\
\text { count after } \\
12 \mathrm{hr} \\
\left(\times 10^{-5}\right)\end{array}$} \\
\hline & & $\mathrm{Mn}^{2+}$ & Control & \\
\hline \multirow{2}{*}{$\begin{array}{l}\text { Difco Todd-Hewitt broth } \\
+0.5 \%(v / v) \text { defibrinated } \\
\text { sheep blood }\end{array}$} & Q-43x (virulent) & \pm & $\bar{t}$ & $\begin{array}{r}50 \\
310\end{array}$ \\
\hline & Q-496 (avirulent) & + & $\bar{t}$ & $\begin{array}{r}15 \\
240\end{array}$ \\
\hline \multirow[t]{2}{*}{$\begin{array}{l}\text { CAT medium (Marmur \& } \\
\text { Hotchkiss, 1955) }\end{array}$} & Q-43x & \pm & $\bar{t}$ & $\begin{array}{r}24 \\
105\end{array}$ \\
\hline & $Q-496$ & \pm & $\bar{t}$ & $\begin{array}{r}4 \\
125\end{array}$ \\
\hline \multirow{2}{*}{$\begin{array}{l}\text { Difco Todd-Hewitt broth } \\
+0.5 \%(v / v) \text { defibrinated } \\
\text { sheep blood }\end{array}$} & M-18 (virulent) & $\stackrel{+}{-}$ & $\overline{+}$ & $\begin{array}{r}43 \\
305\end{array}$ \\
\hline & $18 \mathrm{AM}^{-}$(avirulent) & $\stackrel{+}{-}$ & - & $\begin{array}{r}7 \\
850\end{array}$ \\
\hline \multirow[t]{2}{*}{ CAT medium } & $M-18$ & $\begin{array}{l}+ \\
-\end{array}$ & $\bar{t}$ & $\begin{array}{r}56 \\
110\end{array}$ \\
\hline & $18 \mathrm{AM}^{-}$ & \pm & $\bar{t}$ & $\begin{array}{r}4 \\
710\end{array}$ \\
\hline
\end{tabular}

By using a related pair of virulent and avirulent strains (Q-43x, Q-496), it was determined that maximum inhibition of multiplication for both strains occurred at a

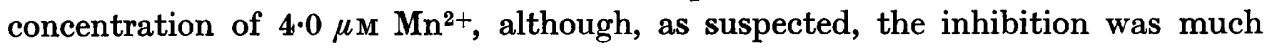
greater in avirulent cultures (Fig. 2).

Table 2 shows that the inhibitory effects of $\mathrm{Mn}^{2+}$ on multiplication of virulent and avirulent streptococci were not restricted to one medium, but occurred in other media that supported the multiplication of streptococci. 


\section{Effects of other cations on multiplication}

It was found (Firshein, 1962) that the stimulatory effects of $\mathrm{Mn}^{2+}$ on multiplication of pneumococci were annulled by the addition of $\mathrm{Ca}^{2+}$. Similarly, in studies with streptococci strains $Q-43 X$ and Q-496 (Table 3), a substantial portion of the inhibition of multiplication of both organisms by $\mathrm{Mn}^{2+}$ could be prevented by the addition of $\mathrm{Ca}^{2+}$ to a level of $4 \cdot 0 \mu \mathrm{M}$.

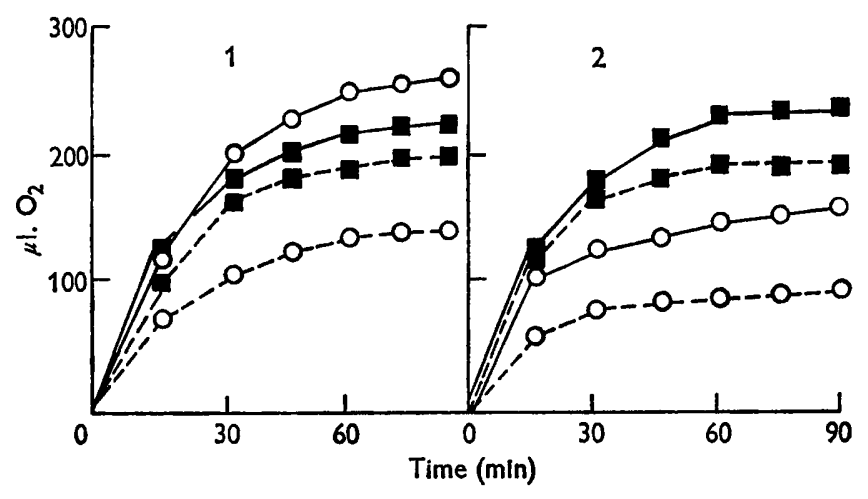

Fig. 3. Effects of $\mathrm{Mn}^{2+}$ on oxygen uptake of virulent and avirulent strains of group $\mathbf{A}$ streptococci in suspensions containing glucose. For concentration of $\mathbf{M n}^{2+}$, see Table 1 . Concentration of glucose was the same as that in washed suspensions (50 $\mu \mathrm{M})$. Endogenous rates are not shown on the graph because they were negligible for all strains tested. 1. Strain Q-43X (virulent) and Q-496 (avirulent). 2. M-18 (virulent) and $18 \mathrm{AM}^{-}$(avirulent). Solid lines, glucose alone; dashed lines, glucose $+\mathbf{M n}^{2+}$. (O), virulent; ( $\square$ ), avirulent. Inocula for all strains were adjusted to the same number, $8.5 \times 10^{8}$ viable cocci $/ \mathrm{ml}$.

Table 8. Reversal of the inhibitory effects of $M n^{2+}$ on multiplication of streptococci by $\mathrm{Ca}^{2+}$

Medium was brain heart infusion neopeptone blood broth (Firshein \& Zimmerman, 1964). Inocula: $\left(\times 10^{5}\right)$, strain $Q-43 x, 24 ; Q-496,15$.

\begin{tabular}{|c|c|c|c|}
\hline \multirow{4}{*}{$\begin{array}{c}\text { Organism } \\
\text { Q-43x (virulent) }\end{array}$} & \multicolumn{2}{|c|}{ Additions (to $\mu \mathrm{M}$ ) } & \multirow{2}{*}{$\begin{array}{c}\text { Viable } \\
\text { count after } \\
12 \mathrm{hr} \\
\left(\times 10^{-5}\right)\end{array}$} \\
\hline & $\mathrm{Ca}^{2+}$ & $\mathrm{Mn}^{2+}$ & \\
\hline & . & • & 340 \\
\hline & . & $4 \cdot 0$ & 45 \\
\hline & 0.4 & $4 \cdot 0$ & 80 \\
\hline & $4 \cdot 0$ & $4 \cdot 0$ & 290 \\
\hline & $8 \cdot 0$ & $4 \cdot 0$ & 200 \\
\hline & 0.4 & • & 300 \\
\hline & $4 \cdot 0$ & . & 245 \\
\hline & $8 \cdot 0$ & - & 190 \\
\hline Q-496 (avirulent) & • & $\cdot$ & 200 \\
\hline & . & $4 \cdot 0$ & 10 \\
\hline & 0.4 & $4 \cdot 0$ & $\mathbf{3 0}$ \\
\hline & $4 \cdot 0$ & $4 \cdot 0$ & 250 \\
\hline & 8.0 & 4.0 & 150 \\
\hline & 0.4 & • & 200 \\
\hline & $4 \cdot 0$ & - & 410 \\
\hline & $8 \cdot 0$ & . & 300 \\
\hline
\end{tabular}


Several other divalent cations did not exert inhibitory effects on multiplication of group A streptococci (Table 4). One cation, $\mathrm{Mg}^{2+}$, enhanced the multiplication of virulent and avirulent strains slightly.

Effects of $M n^{2+}$ on respiration, nucleic acid synthesis, and protein synthesis

The ability of $\mathrm{Mn}^{2+}$ to affect respiration of pneumococci (Firshein, 1962) suggested a study of the effects of $\mathrm{Mn}^{2+}$ on respiration of group A streptococci. Using oxidation of glucose as a parameter of respiration, it was found (Fig. 3) with two related pairs of virulent and avirulent strains that $\mathbf{M n}^{2+}$ depressed oxygen uptake in both virulent

\section{Table 4. Effects of $\mathrm{Mg}^{2+}, \mathrm{Zn}{ }^{2+}$, and $\mathrm{Fe} \mathrm{e}^{2+}$ on multiplication of group $\mathrm{A}$ streptococci}

Since no inhibitory effects on multiplication were exerted by the cations tested, only the results with one concentration (indicated in parentheses) are shown. Medium was brain heart infusion neopeptone blood broth (Firshein \& Zimmerman, 1964). Inocula $\left(\times 10^{5}\right)$; strain $Q-43 x, 8$; strain $Q-496,5$; strain $M-18,15$; strain $18 \mathrm{AM}^{-}, 15$; strain $\mathrm{M}_{-1} 6,20$; strain 6 AM- $^{-}, 12$.

\begin{tabular}{|c|c|c|}
\hline $\begin{array}{c}\text { Organism } \\
\mathrm{Q-43 \times} \text { (virulent) }\end{array}$ & $\begin{array}{c}\text { Cation tested } \\
\mathrm{Mg}^{2+}(2 \cdot 0 \mu \mathrm{M}) \\
\mathrm{Zn}^{2+}(4 \cdot 0 \mu \mathrm{M}) \\
\mathrm{Fe}^{2+}(4 \cdot 0 \mu \mathrm{M}) \\
\text { None }\end{array}$ & $\begin{array}{c}\text { count after } \\
12 \mathrm{hr}\left(\times 10^{5}\right) \\
520 \\
210 \\
220 \\
300\end{array}$ \\
\hline Q-496 (avirulent) & $\begin{array}{l}\mathbf{M g}^{2+} \\
\mathbf{Z n}^{2+} \\
\mathbf{F e}^{2+} \\
\text { None }\end{array}$ & $\begin{array}{l}250 \\
100 \\
150 \\
105\end{array}$ \\
\hline M-18 (virulent) & $\begin{array}{l}\mathbf{M g}^{2+} \\
\mathbf{Z n}^{2+} \\
\mathbf{F e}^{2+} \\
\text { None }\end{array}$ & $\begin{array}{l}\mathbf{9 5 0} \\
\mathbf{5 5 0} \\
\mathbf{4 4 0} \\
\mathbf{5 5 0}\end{array}$ \\
\hline $18 \mathrm{AM}^{-}$(avirulent) & $\begin{array}{l}\mathrm{Mg}^{2+} \\
\mathbf{Z n}^{2+} \\
\mathrm{Fe}^{2+} \\
\text { None }\end{array}$ & $\begin{array}{r}1000 \\
730 \\
680 \\
700\end{array}$ \\
\hline M-6 (virulent) & $\begin{array}{l}\mathbf{M g}^{2+} \\
\mathbf{Z n}^{2+} \\
\mathrm{Fe}^{2+} \\
\text { None }\end{array}$ & $\begin{array}{r}210 \\
95 \\
90 \\
100\end{array}$ \\
\hline $6 \mathrm{AM}^{-}$(avirulent) & $\begin{array}{l}\mathbf{M g}^{2+} \\
\mathbf{Z n}^{2+} \\
\mathbf{F e}^{2+} \\
\text { None }\end{array}$ & $\begin{array}{l}450 \\
220 \\
160 \\
200\end{array}$ \\
\hline
\end{tabular}

and avirulent-cell suspensions containing glucose. However, the inhibitory effects were more pronounced in virulent than in avirulent-cell suspensions, particularly for one pair ( $Q-43 x$ and $Q-496)$. These results were surprising in view of the fact that multiplication was depressed to a greater extent in avirulent strains than virulent strains. To test whether other metabolic systems in avirulent strains may have been affected by $\mathrm{Mn}^{2+}$, measurements of nucleic acid and protein synthesis 
were made in washed-cell suspensions in the presence and absence of the cation. In addition, effects of $\mathrm{Mn}^{2+}$ on nucleic acid and protein syntheses of virulent strains were determined. The results of these experiments, replicated several times (Table 5), demonstrated that: (1) nucleic acid synthesis and protein synthesis were depressed equally from control levels in suspensions of virulent strains; (2) only nucleic acid synthesis was depressed in suspensions of avirulent strains, protein synthesis was largely unaffected; and (3) nucleic acid synthesis was depressed to a much greater extent from control levels in suspensions of avirulent than virulent strains.

\section{Table 5. Effects of $\mathrm{Mn}^{2+}$ on nucleic acid and protein synthesis of} Group A streptococci

Concentration of $\mathrm{Mn}^{2+}$ was 4.0 $\mu \mathrm{M}$. Preparation of washed cocci, suspending medium, extraction and measurement of nucleic acids and protein were as described previously (Firshein, 1961).

\begin{tabular}{|c|c|c|c|c|c|}
\hline \multirow[b]{2}{*}{ Organism } & \multicolumn{2}{|c|}{ Additions } & \multicolumn{3}{|c|}{$\begin{array}{l}\% \text { increase over zero } \\
\text { time after } 70 \mathrm{~min} .\end{array}$} \\
\hline & $\mathrm{Mn}^{2+}$ & Control & DNA & RNA & Protein \\
\hline \multirow[t]{2}{*}{ Q-43x (virulent) } & + & - & 50 & 45 & 42 \\
\hline & - & + & 69 & 54 & 64 \\
\hline \multirow[t]{2}{*}{ Q-496 (avirulent) } & + & - & 25 & 23 & 65 \\
\hline & - & + & 68 & 71 & 74 \\
\hline \multirow[t]{2}{*}{ M-18 (virulent) } & + & - & 14 & 10 & 15 \\
\hline & - & + & 21 & 18 & 23 \\
\hline \multirow[t]{2}{*}{$18 \mathrm{AM}^{-}$(avirulent) } & + & - & 1 & - & 14 \\
\hline & - & + & 13 & 14 & 16 \\
\hline \multirow[t]{2}{*}{ M-6 (virulent) } & + & - & 21 & 20 & 18 \\
\hline & - & + & 34 & 40 & 31 \\
\hline \multirow[t]{2}{*}{$6 \mathrm{AM}^{-}$(avirulent) } & + & - & - & 1 & 21 \\
\hline & - & + & 24 & 25 & 19 \\
\hline
\end{tabular}

The helpful criticism of $\mathrm{Dr}$ W. Braun in preparing the manuscript is gratefully acknowledged. The investigation was supported by a grant from the Public Health Service, CA-06343-02.

\section{REFERENCES}

Firshein, W. (1960). DNA synthesis, respiration, and virulence in pneumococci. Ann. N.Y. Acad. Sci. 88, 1054.

Firshein, W. (1961). Effects of deoxyribonucleic acid products on deoxyribonucleic acid synthesis of virulent and avirulent pneumococci. J. Bact. 82, 169.

Firshein, W. (1962). Effects of manganese and enzymatic deoxyribonucleic acid digests on population changes and respiration of pneumococci. $J$. Bact. 84, 478.

Firshein, W. \& BraUn, W. (1960). Effects of enzymatic deoxyribonucleic acid digests on population changes and deoxyribonucleic acid synthesis of pneumococci. J. Bact. 79, 246.

Firshein, W. \& Zimmerman, E. M. (1964). In vitro and in vivo effects of deoxyribonucleic acid degradation products on virulent and avirulent group A streptococci. J. gen. Microbiol. 36, 237.

Marmur, J. \& Hotchкiss, R. D. (1955). Mannitol metabolism, a transferable property of pneumococcus. J. biol. Chem. $214,383$. 